This is an Accepted Manuscript of an article published by Taylor \& Francis in Housing Studies on Volume 33, 2018.

\title{
Schelling-Type Micro-Segregation in a Hassidic Enclave of Stamford-Hill
}

\section{Corresponding Author:}

Dr Shlomit Flint Ashery

Email shlomit.flint@ucl.ac.uk

\begin{abstract}
This study examines how non-economic inter- and intra-group relationships are reflected in residential pattern, uses a mixed methods approach designed to overcome the principal weaknesses of existing data sources for understanding micro residential dynamics. Micro-macro qualitative and quantitative analysis of the infrastructure of residential dynamics offers a holistic understanding of urban spaces organised according to cultural codes. The case study, the Haredi community, is composed of sects, and residential preferences of the Haredi sect members are highly affected by the need to live among "friends" - other members of the same sect. Based on the independent residential records at the resolution of a single family and apartment that cover the period of 20 years the study examine residential dynamics in the Hassidic area of Stamford-Hill, reveal and analyse powerful Schelling-like mechanisms of residential segregation at the apartment, building and the near neighbourhood level. Taken together, these mechanisms are candidates for explaining the dynamics of residential segregation in the area during 1995-2015.
\end{abstract}

\section{Keywords}

Hassidic, Stamford-Hill, Segregation, Residential, London

\section{Acknowledgments}

This research was carried out under a Marie Curie Fellowship PIEF-GA-2012-328820 while based at Centre for Advanced Spatial Analysis (CASA) University College London (UCL). 


\section{Introduction}

The dynamics of social and ethnoreligious segregation, which form part of our urban landscape, are a central theme of housing studies. Despite the interest raised by large-scale aspects of the Haredi (the strictly orthodox Jews) organization, who tend to form sizeable enclaves in large cities around the globe, including New-York and London (Valins, 2003), very little has been written about their micro-resolution residential dynamics. Using a mixed methods approach to analyse data from extensive bottom-up micro resolution field survey that took place in Stamford-Hill, this paper investigates whether the tendency of each sect's members to be different from the others is expressed in their residential pattern. Such method can recognize real and previously unknown dynamic processes, which other studies in the field may have overlooked as they have tended to work with patterns. This study adds to the existing body of knowledge by integrating bottom-up knowledge of the impact of social structures and networks of the Haredi Jews on residential dynamics, and explores how the human need for a sense of belonging and continuity leads to the development of micromechanisms that improve the individual's ability to cope with the challenges of urban life.

Members of Jewish Haredi society define themselves by their commitment to Halacha, the dominant protocol determining Jewish ritual and translation of the commandments into daily practice. Expression of this distinctiveness is found in the clear tendency to avoid the larger Jewish society, live among other Haredi of the same or close sects, engage in a strict practice of ritual and maintain the lifestyles reflecting their rabbinical origins (Berman, 2009). While the Haredi community in Stamford-Hill, this study's case, appears unified to outsiders, it is actually distinguished by internal, nuanced distinctions among sects and sub-sects (Valins, 2003). These internal divisions are affecting the values, religious rituals, and normative behaviour, and vary from one sub-sect to another in terms of clothing, language and attitudes towards working as opposed to full-time Torah (Bible) study. In the Haredi world, the basic lifestyle and ritual orientation of each sub-sect express theological stances and historical tradition determined by their association to the sect's leader (Shilhav and Friedman, 1985).

In a close-knit community, neighbours' identity and a flat's genealogy are important components of the stated preferences for making residential choices. The residential preferences of Haredi individuals to live among other members of the same sub-sect to which they belong - together with the relatively similar economic status of the majority of Haredi families in Stamford-Hill, no matter which sect they belong, enables focusing on the role of cultural identity in the creation of residential patterns. The relationships between Haredi sects are likewise expressed in the residential preferences of their individual members. The Haredi individual is committed to a community-determined segregation lifestyle that is observed in several communities and affects its choice of residential location. According to Shilhav and Friedman (1985) Haredim "... voluntary segregation is based on a pre-existing ideological concept which reinforces itself, even when people's economic and socio-economic status improves..." It is important for this study that most of the Haredi residents of Stamford-Hill belong to Hassidic sub-sects; which all differ in terms of their self-identity and status within Haredi society and wish to live among their group (Gonen, 2006). 
Similar to other religious neighbourhoods around the world, Stamford-Hill has become a Haredi neighbourhood over several decades, its character was influenced primarily by its central location and individual-level decision making. These circumstances are reflected in residential patterns, enabling maintenance of individual-community relations together with a reproduction of the sects' hierarchy. The relations between these Haredi sects reflect those within the entire Haredi world while local circumstances affect the specific links connecting the sub-sects. The research thus considers Stamford-Hill's residential pattern as driven by the interactions between householders of different groups and investigates whether the tendency to reside among people of their own groups can explain non-economic residential patterns there. The paper begins with the theoretical framework (Section 2), describing the effects of communal identity on inter-group residential relations and presenting the Non-economic segregation, which provides the context for the Hassidic residential behaviour. Section 3 presents the details of Stamford-Hill population groups, followed by the methodology of the study in Section 4. Section 5 presents the inter-building and intra-building segregation dynamics, and Section 6 presents Inter-sect relations. Section 7 discusses the findings, their relevance to theories of residential dynamics and the impact of intra-communal and inter-sect relations on the spatial organization.

\section{Residential segregation}

\subsection{Communal identity and Inter-group residential relations}

Research on residential choices and "geography of opportunity" (Rosenbaum, 1995; Clark, and Dieleman, 1996; Karsten, 2007), state that in addition to labour migration, housing and access to higher education, individual identity play an important role in determining neighbourhood choice (Twigger-Ross and Uzzell, 1996; ); usually influenced by individuals' views of their own identity and that of their neighbours (McGarrigle and Kearns, 2009; Clark and Coulter, 2015). According to the social identity theory (Tajfel 1972), individuals' behaviour reflects identification with larger societal units. Individuals define themselves in terms of their belonging to a social category, adopt its norms and lifestyle, and eventually create a group (Abrams and Hogg 1990). More differentiated and context-bound works on identity, residential selection and segregation in different countries and cities show that identities might be particularly intense in mixed cities (South et al, 2011) where individuals prefer to form ties with others living close by and of the same group (Blumenstock et al, 2014; Musterd et al, 2016). Subject to factors such as affordability and availability of appropriate accommodation, they may be driven into segregating themselves from influences of unwelcomed groups and concentrating in what they perceive as friendly social environments (Johnston et al, 2007; Arbaci, 2007; Colomb, 2017).

Ibraimovic and Masiero (2014) show that the housing market in cities is a mirror of housing demand from different groups, whose voluntary segregation preferences - positive for members of the same or close groups and negative for others - and preferences for location, create the spatial distribution of housing tenures (Atkinson \& Flint, 2004; Briggs, 2005; Phillips, 2009, Andersen et al, 2016). The housing market, in this sense, does not influence segregation but is a result of this dynamic (Andersson et al, 2016; Musterd et al, 
2016). Other domains of segregation (e.g., voluntary association) and hidden value homophily (e.g., information or attitudes) may drive the inbreeding process (Kalmijn, 1998: 410; Lloyd, 2015) as people's personal networks are homogeneous with regard to many sociodemographic, behavioural, and intrapersonal characteristics (McPherson et al, 2001; Blumenstock et al, 2014). Over time, they may create "nested" places in specific urban areas at various urban scales: buildings, street blocks, neighbourhoods, and larger enclaves, with the smaller scales having more intense social interactions (Kusenbach 2008; South et al., 2011). The degree to which these concentrations form communities depends on the presence of a shared territory, significant social ties, and meaningful social interactions (Guest et al. 2006). Segregation, therefore, can be thus conceptualised both as a static distribution of groups across space and as a dynamic phenomenon whereby such socio-spatial distribution undergoes change over time (Andersen et al, 2016).

The effect of cooperation between a city's free individuals on its urban structure was considered, for example, by the Chicago School at the beginning of the 20th century. According to their "invasion-succession" theory (Park, Burgess, \& McKenzie, 1925), spatial segregation is a dynamic phenomenon whereby such socio-spatial distribution undergoes change over time, and therefore reflects individuals' preference to cooperate with others as a means of promoting their welfare (Wirth 1928/1998). Current models, however, claim that the tendency to cooperate is more complicated. Modern, urban individuals are driven by the constant assessments of risks embedded in other people. As individuals carefully select those to be trusted, they actually engage in the building of self-identity. In Giddens' (1984) words, "Self-identity is not a distinctive trait or even a collection of traits [. . . ] possessed by the individual. It is the self as reflexively understood by the person in terms of her or his biography" (Giddens 1984, 53). The person's biography is, inevitably, connected to the urban sphereagain, in a complicated manner. One example of this connection is the sub-national 'Internal' migratory dynamics of Middle-class individuals and families moving for education (Levy and Lee, 2011; Fielding, 2012). With the rise individualism, the tendency to move in order to reside in the 'right neighbourhood' and access the 'right education' (Butler et al, 2007) consists one of the most conspicuous signifiers of contemporary urban and rural change in the UK (Smith and Jons, 2015).

Researchers who examined intergroup relations among Mormons, Catholics, and Protestants (Finke, 1997; Boal, 2010; Tausch et al., 2011) raise doubt regarding the degree to which a-spatial segregation of posttraditional society is relevant for understanding the social life of ultra-religious groups residing in current multicultural cities. The parochial realm - a term coined by Hunter (1985) and developed by Lofland (2009) - is especially meaningful in the case of religious communities. While modern, post-traditional identities are individual, biography-oriented, and institution-oriented products, communal identity provides a central pillar for the ultra-religious person and an important source of one's self-identity. Moreover, belonging to the ultrareligious community is the main source of strength and vitality - of minimizing the risk to the self of interacting with others, in Giddens' terms-and the stronger it gets, the more impact it has on the individual's norms and lifestyle. The intense awareness of religious identity motivates individuals to exclusively encounter people with the same values and affiliations (Peach, 2006, Shuttleworth et al, 2012). Therefore, and in a contrast to the 
general modern British society which highlights the individual's qualities and preferences as the means for defining one's identity, the importance given in the Haredi world to appropriate education is expressed in their need to live, from the cradle to the grave, within the community, where the social order is already established as a basis for an individual's definition. Being born and raised into the social and educational environment of their community, where access to appropriate social and educational institutions is already guaranteed, Haredi people do not need such "Internal migration" (Fielding, 2012). Identity concerns are the paramount factor in housing decisions for people belonging to Haredi groups, who tend to limit their social contacts to people belonging to the same sects and sub-sects, preferably inside the defined enclave. Each sub-sect cooperates in its own religious and educational institutions and exclusive social networks and tends to compete with "others" over spatial-cultural dominance, emphasizing the strategic influence played by spatial homogeneity (Valins 2003).

\subsection{Non-economic segregation}

The UK literature concerning the housing pattern of ethnic minorities tended to include aspects of both choices - property type, size and location - and constraints - direct and indirect discrimination from housing exchange professionals and socio-cultural considerations (Ratcliffe, 2009; Berg \& Sigona, 2013). This Sociocultural housing approach often blurs the specific mechanisms and impact, whether sociocultural motives or economic, that generate spatial patterns. Many researchers study residential relationships based on empirical observation (Krivo, et al. 1998; Britton 2011), while others explain residential choices using deductive assumptions regarding economic and socio-cultural factors (Clark and Dieleman, 1996; Bisin et al, 2016). In both cases, differences in family situation, lifestyle and changes in the life cycle that were traditionally seen as factors of greatest importance for residential choices, usually overlap-whether conceptually or empirically-with economic factors, such as tenure preferences, dwelling requirements, flexibility and security, as well as socio-culturaleconomic interactions (Catney and Simpson, 2010; Finney and Jivraj 2013; Clark and Coulter, 2015, Smith and Jons, 2015). Although these approaches help interpret the spatial manifestation of intergroup differences, they are limited in distinguishing between the roles of economic and noneconomic factors in actual residential dynamics (Massey and Denton 1985; Krivo et al., 1998; Johnston, Poulsen, and Forrest, 2007).

In the mid-1970's, Speare's classification identified the socio-economic characteristics of the individual and the household on the one hand, and the socio-economic status of the housing and neighbourhood on the other, as the main factors for analysis of householders' residential behaviour (Speare et al, 1975; Kasarda, 1978). It is now common to distinguish between revealed preferences, actual individual/household behaviour and stated preferences, individuals' declared attitudes and intentions. As many studies show, a comparison between stated preferences, which are found by asking people directly about how they would prefer to live and why, and revealed preferences, which are found by examining how people actually live, lays the foundation for understanding residential dynamics as an outcome of individuals' choices (Benenson et al, 2002). 
Particularly the comparison of the two may reflect the roles of socio-cultural motives for segregation, expressed in revealed preferences, and the economic constraints, affecting the revealed behaviour.

A basic approach to non-economic segregation between householders who belong to one of two ethnic groups - although not on such a highly specific group of the population - was offered by -Sakoda and -Schelling (Sakoda, 1971; Schelling, 1978). According to them, each householder considers the surrounding population to consist of 'friends', that is, householders belonging to the same group, and 'strangers' - householders belonging to other groups. Sakoda and Schelling further reduced the non-economic factors influencing the householder's decision to stay or to move to a single variable: the fraction of 'friends' within the householder's neighbourhood. According to Schelling's model, householders aim at residing in a neighbourhood where the fraction of friends, F, is above a certain threshold. In the abstract versions of a model, which consider the square grid of cells, each populating one householder only, a threshold value of $F$ varies lays within the interval 1/4 $1 / 3$, depending on the other model parameters. This means that the tendency of a householder to reside within a neighbourhood where the fraction of friends is above one third eventually results in complete residential segregation. He then concluded that a relatively weak tendency to congregate is, in the long term, sufficient to create full segregation between members of two groups within the urban space and the exclusion of "others" (Speare et al, 1975). Regarding the importance of communal identity to the individuals, the distinction between the will to congregate with "friends" and the desire to segregate from "others" may be particularly relevant for the research of religious groups. Despite the essential advance in studying Schelling model in its abstract form, examples of the real-world dynamics that can be described by the Schelling-type rules are very few. In what follows the research aim to verify the same idea in the real world and investigate whether the tendency to reside among people of their own sects can explain residential patterns there.

\section{The case study of the Hassidic community of Stamford-Hill}

Jewish settlement in Stamford-Hill began as early as the 18th century when Jewish merchants built their country homes in what was then a rural area. In the early 20th century, pogroms and persecution in Russia and Eastern Europe led to the immigration of 100,000 Jews into England, and many of these passed through London's East End and moved north through Hackney towards Stamford-Hill. During the 1930's and immediately post WW2 the Jewish population was swelled by refugees and Holocaust survivors, many of them Haredim. Since the war there has been further, albeit more limited, Jewish immigration, for example from Hungary following the revolution in 1956 and Aden in 1967 as well as a more recent influx of Jews from the Yemen.

Today, Stamford-Hill is particularly known for its 30,000 Ashkenazi ultra-Orthodox Hasidic Jews (DESTINATION Hackney, 2015), characterized by conventional devotion to Torah study and strict adherence to Jewish laws regarding diet, prayer, social and sexual relationships, Sabbath and festivals. The lives of the Hassidim focus around the Admor's (Rebbe, their religious leader) courtyard, who fulfils the spiritual role of the link between people and God, and is a central leader in the daily lives of his community. The Hassidim usually 
marry others from the same Hassidic courtyard and most of their social relations takes place within it (Green, 2001). High fertility among the Haredi communities, the area has one of highest birthrates in the UK, with a crude birth rate of more than 25 per 1,000 of the population - twice as high as the UK average (ONS, 2012) and limited career training, prevent economic improvement for the majority of Haredi Jewish households (Gonen, 2006). The role of economic considerations is not completely absent, though, as Haredi households have variations in their economic positions. A gradually growing minority of the community is of more comfortable means but over $50 \%$ are on means-tested benefits (Interlink, 2010). However, the Haredi community is bound by a shared faith and culture and people in different economic circumstances live side by side. Although individuals are free to live anywhere in this densely populated neighbourhood, households must comply with the sect's directives.

The large number of 75 synagogues in the research area (Figure 1) reflects the diversity within the Haredi community, with different liturgical traditions. Definitions of the sects derived from the substantial selfidentity of each rabbinical dynasties and courtyards of the Hassidim also expressed in lifestyle and appearance and reflect the internal Haredi discourse. The largest groups are the Satmar, the Gerer, the Belzer and the Bobover (Table 1). Other London based communities include the Kosov, the Biala, the Machnovka, the Chernobyl, the Skver, the Rachmastrivka, the Vizhnitz, the Karlin-Stolin and the Sassov. All taking their name from the village or town in Poland, Hungary or Ukraine where they originated, and each distinguished by some slight variation of religious practice and of dress.

Unlike other Hassidic sects, Chabad's latest Rebbe, Menachem Schneeson, has not been succeeded by another Rebbe, and Chabad is deeply divided with regard to messianism (the notion that the Rebbe was/is the messiah), a claim that seems to put them on a different trajectory than from nearly all other sects, including Hasidic groups with similar norms and practices. Chabad is also unusually large and well-staffed organization, extremely geared to outreach other Jews. More than $70 \%$ of Chabad adherent join the movement later in their life. Besides English, most British Chabad Rabbis speak Yiddish with a Lithuanian accent and grammar, unlike other Hassidim (except for Stolin-Karlin) who speak Polish-Hungarian Yiddish. Unlike the Hassidic dress code of wearing a shtreimel and either a bekishe or a rekel, most Chabad men wear business attire with coloured shirts during the week and wear a Chabad version of the Lithuanian Kappote on the Sabbath.

This socio-cultural tendency, together with the innate conflict with modern, secular and even modernOrthodox lifestyles, has motivated voluntary territorial separation of the Haredi population into an enclave of sorts (Shilhav and Friedman, 1985). At the urban level, the Haredi areas of Stamford-Hill are extremely segregated within the mixed London Borough of Hackney. The Haredi live in separate streets from the other ethnic groups in the Borough of Hackney, surrounded mainly by a mixture of negligible numbers of North African, Indian, Iraqi, Persian, Yemeni and Adeni Jews and other Lithuanians Haredi sects (Litvak) whose presence continuously declines, as well as Chinese, East European, Turkish and Kurdish communities.

Representatives of the Hassidim are involved in planning for the community through The Interlink Foundation, Orthodox Jewish Voluntary Action, that advocating for community needs, and helping influence 
policy-makers to work collaboratively. Interlink (2010) explain that Haredim are continually engaged in adapting and extending the housing stock to meet their needs with hundreds of loft extensions, dormers and back extensions. However, prices in Stamford-Hill, both of rental units and units for sale, are relatively high and reflects the area's attractiveness with a wide range of religious institutions and rabbinical courts active in the area.
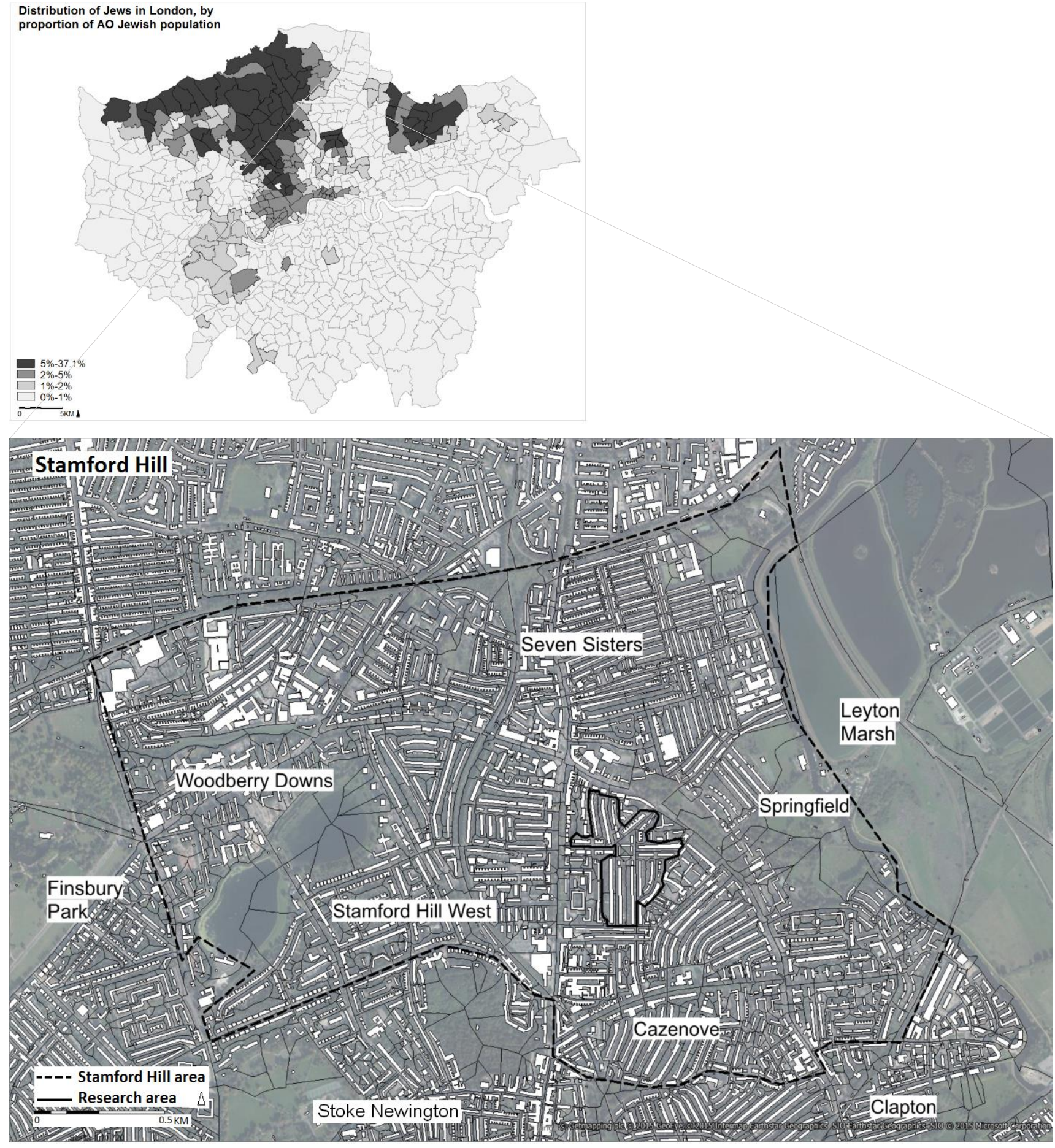

Figure 1: (a) the distribution of the Jewish population in London; (b) Stamford-Hill. 2011 Census in open data 


\begin{tabular}{|c|c|c|c|c|}
\hline Name & $\begin{array}{c}\text { Current (or last) } \\
\text { Rebbe }\end{array}$ & Founder & Headquartered In & City/Town of Origin \\
\hline Satmar & $\begin{array}{l}\text { Aaron Teitelbaum (b. } \\
\text { 1947); } \\
\text { Zalman Leib } \\
\text { Teitelbaum (b. 1952) }\end{array}$ & $\begin{array}{l}\text { Yoel } \\
\text { Teitelbaum (1887- } \\
\text { 1979) }\end{array}$ & $\begin{array}{l}\text { Kiryas Joel, New } \\
\text { York; } \\
\text { Williamsburg, } \\
\text { Brooklyn }\end{array}$ & $\begin{array}{l}\text { Satu Mare, Hungary } \\
\text { (now in Romania) }\end{array}$ \\
\hline Ger (er) & $\begin{array}{l}\text { Yaakov Aryeh } \\
\text { Alter (b. 1939) }\end{array}$ & $\begin{array}{l}\text { Yitzchak Meir } \\
\text { Alter (1799-1866) }\end{array}$ & Jerusalem, Israel & $\begin{array}{l}\text { Góra Kalwaria, } \\
\text { Russian Empire (now } \\
\text { in Poland) }\end{array}$ \\
\hline Belz (er) & $\begin{array}{l}\text { Yissachar Dov } \\
\text { Rokeach }\end{array}$ & $\begin{array}{l}\text { Sholom } \\
\text { Rokeach (1781- } \\
1855)\end{array}$ & Jerusalem, Israel & $\begin{array}{l}\text { Belz, Galicia, Austria- } \\
\text { Hungary / Poland } \\
\text { (now in Ukraine) }\end{array}$ \\
\hline Bobov (er) & $\begin{array}{l}\text { Ben Zion Aryeh } \\
\text { Leibish Halberstam; } \\
\text { Mordechai Dovid } \\
\text { Unger }\end{array}$ & $\begin{array}{l}\text { Shlomo Halberstam } \\
\text { of Bobov (1847- } \\
\text { 1905) }\end{array}$ & $\begin{array}{l}\text { Borough } \\
\text { Park, Brooklyn }\end{array}$ & $\begin{array}{l}\text { Bobowa and Sanz, } \\
\text { Galicia, Austria- } \\
\text { Hungary (now in } \\
\text { Poland) }\end{array}$ \\
\hline $\begin{array}{l}\text { Kosov (See: } \\
\text { Vizhnitz) }\end{array}$ & Shraga Feivish Hager & $\begin{array}{l}\text { Rabbi Menachem } \\
\text { Mendel Hager }\end{array}$ & $\begin{array}{l}\text { Borough Park, } \\
\text { Brooklyn, Jerusalem } \\
\text { and Tzfas, Israel }\end{array}$ & Kosiv, Ukraine \\
\hline
\end{tabular}

\section{Vizhnitz}

(The Vizhnitz

dynasty is the

best known

branch of the

Mordechai Hager

original Kosover

dynasty)
Menachem Mendel

Hager of

Kosov (1830-1884)
Vyzhnytsia, Bukovina, Austria-Hungary (now in Ukraine)

\begin{tabular}{lllll}
\hline \multicolumn{3}{c}{ Avraham Yerachmiel } & & \\
Rabinowicz; & Yitzchok Yaakov & Jerusalem, Israel; & \\
Biala & Yaakov Menachem & Rabinowicz (died & Bnei Brak, Israel; & Borough \\
& Rabinowicz; & 1905) & Park, Brooklyn & \\
& Aaron Rabinowicz & & \\
\end{tabular}




\begin{tabular}{|c|c|c|c|c|}
\hline Machnovka & Yehoshua Rokeach & $\begin{array}{l}\text { Yosef Meir } \\
\text { Twersky of } \\
\text { Machnovka }\end{array}$ & Bnei Brak, Israel & Machnovka, Ukraine \\
\hline Chernobyl & several & $\begin{array}{l}\text { Menachem } \\
\text { Nachum Twerski of } \\
\text { Chernobyl (1730- } \\
\text { 1797) }\end{array}$ & $\begin{array}{l}\text { Bnei Brak, Israel; } \\
\text { Ashdod, Israel; } \\
\text { Boro Park, Brooklyn }\end{array}$ & Chernobyl, Ukraine \\
\hline Skver & $\begin{array}{l}\text { David Twersky (b. } \\
\text { 1940) }\end{array}$ & Yitzchak Twersky & $\begin{array}{l}\text { New Square, New } \\
\text { York }\end{array}$ & $\begin{array}{l}\text { Skvira, Russian Empire } \\
\text { (now in Ukraine) }\end{array}$ \\
\hline Rachmastrivka & $\begin{array}{l}\text { Rebbe Duvid (David) } \\
\text { Twersky } \\
\text { of Rachmastrivka- } \\
\text { Yerushalayim }\end{array}$ & Yochanan Twersky & $\begin{array}{l}\text { Borough Park, } \\
\text { Brooklyn, New } \\
\text { York and } \\
\text { in Jerusalem, Israel }\end{array}$ & Rotmistrivka, Ukraine \\
\hline Karlin-Stolin & $\begin{array}{l}\text { Baruch Meir Yaakov } \\
\text { Shochet }\end{array}$ & $\begin{array}{l}\text { Aaron ben Jacob of } \\
\text { Karlin (1736-1772) }\end{array}$ & $\begin{array}{l}\text { Givat Zeev, West } \\
\text { Bank; } \\
\text { Jerusalem, Israel }\end{array}$ & Karlin, Belarus \\
\hline Sassov & $\begin{array}{l}\text { Grand Rabbi Yaakov } \\
\text { Tzvi Erblich }\end{array}$ & $\begin{array}{l}\text { Moshe Leib } \\
\text { Sassover (1745- } \\
\text { 1807) }\end{array}$ & $\begin{array}{l}\text { Monsey, New } \\
\text { York; Ganei Tikva, } \\
\text { Israel }\end{array}$ & $\begin{array}{l}\text { Eastern } \\
\text { Galicia, Ukraine }\end{array}$ \\
\hline $\begin{array}{l}\text { Chabad } \\
\text { Lubavitch }\end{array}$ & $\begin{array}{l}\text { Menachem Mendel } \\
\text { Schneerson (1902- } \\
\text { 1994) }\end{array}$ & $\begin{array}{l}\text { Schneur Zalman of } \\
\text { Liadi (1745-1812) }\end{array}$ & $\begin{array}{l}\text { Crown Heights, } \\
\text { Brooklyn }\end{array}$ & Lyubavichi, Russia \\
\hline
\end{tabular}

Table 1: Rabbinical dynasties of the Hassidic sect in Stamford-Hill, by Sub-sects

4. Methods

4.1 Construction of Stamford-Hill's spatio-temporal population GIS

To investigate residential relationships in the research area among Stamford-Hill's population groups, a detailed spatial-temporal database that contains exact geo-referenced data on families' religious affiliation was conducted. The field research was conducted during 2015 at the level of individual families and apartments. Two interviewers, young Haredi males from the local community, canvassed the neighbourhood and conducted a quantitative-qualitative door-to-door survey. During a one hour interview, the households were asked to identify themselves as well as the apartment's former dwellers, going back 1995. Since people find it difficult to pinpoint and separate why exactly they make particular moves, a reasonable concern is raised regarding the 
reliability of retrospective reports and knowledge of local population turnover. However, several researchers stress that the identity of the previous residents is important for traditional families (Waterman and Kosmin, 1988; Sennett, 2012). The importance of a continuum of residency to traditional populations limit the number of turnovers of flats: While the average housing turnover in the UK is 21 years (ONS, 2015), the average housing turnover for the Haredi population in this research is over 46 years. This tendency leads to the development of flat genealogy of previous occupants, a conclusion confirmed by this research. For the Haredi population, it is highly important that their apartment will be "Kosher". Renting or buying an apartment in which an ultraOrthodox family used to live, ensures a double kosher sink according to the sect's norms, and that the mezuzos (A case comprises a piece of parchment with specific Hebrew verses from the Torah affixed to every doorway in the home) won't be removed once they placed. These norms lead to relatively few turnover of families during the years, enable us to identify of past residents and allow us to understand which sect's members occupied each apartment for the past 20 years.

All other questions were asked related to the present occupants in order to ascertain their socio-spatial behaviour. Householders were also questioned about their motives for choosing the apartment, how long they have been occupying it and asked to rank the relative importance of the apartment's price, their neighbours' identity, and institutional proximity (stated preferences). This field survey also collected data about the location of the synagogues the families attended, whether the apartment was owned or rented, and the source of information about the apartment prior to buying or renting it (revealed preferences). Given the heavy reliance on the primary survey, and in order to ensure consistency and quality, each interviewer was to carry out three pilot interviews to refine approaches and questions. In addition, the field notes were reviewed weekly to ensure consistency across the project. A 5-10\% overlap among the sections under review was maintained in order to evaluate the incoming data and improve accuracy. Despite early apprehensions regarding cooperation, the response rate reached $83 \%$. A high level of cooperation with the survey enabled a comparison between stated and revealed preferences and recognizes similar preferences amongst the groups.

Snowball sampling for in-depth interviews was then used, in which participants are recruited by chain referrals, and 32 in-depth open-ended interviews were conducted with key figures from various fields, provided rich qualitative data. Those involved with the communities were interviewed about spatial relations between the individual and the community, and the economic aspect of the yeshiva in regard to housing. The information was cross-checked with blogs, articles, and Haredi internet sites, which offered a range of different types of knowledge and perspectives on their communities.

Construction of the Stamford-Hill GIS was based on the layers updated for the year 2015, which were provided by the ordnancesurvey.co.uk/opendatadownload/products.html. The characteristics of all the research area's apartments and households were organized as a GIS layer, in which every record in the table is related to the corresponding building. The layer was then included in the area's high-resolution GIS. StamfordHill GIS contains additional layers pertaining to topography, roads, land parcels, and buildings, the latter characterized by use and number of floors. 
Combining the spatial-temporal GIS of residential patterns with information on individuals' preferences and organisational tools enabled evaluation of residential patterns at the level of apartments, buildings and neighborhood. High-resolution mixed methods analysis using CityEngine and MAXQDA as well as more traditional modelling tools such as Python and $\mathrm{R}$ indicated the differences between stated and revealed preferences, presenting a background for an examination of the area with regards to the context of its environs. The research area of Stamford-Hill contains 104 apartments in 7 buildings with another 686 apartments in 406 detached/semi-detached houses. 1165 Households occupy 590 apartments. Another 67 apartments are used by institutions (such as synagogues) and the remaining 71 are shared by households and institutions (such as kindergartens operated within dwellings).

\subsection{Estimation of residential segregation}

Given the exhaustive survey and high response rate, the micro-segregation residential pattern in Stamford-Hill is available at the highest possible resolution of households and buildings. Disaggregated data enable direct estimation of the relationships between households and neighbours in the same and neighbouring buildings. Standard measures of segregation, such as the Dissimilarity Index (Sharma 2012), employ data that are aggregated over the units of a predefined, usually administrative, partition of the area. That aggregated view of space does not allow us, however, to account for the spatial adjacency of the householders of different sects at the resolution of buildings or apartments. The high-resolution data the study collected enables direct estimation of the relation between characteristics of the household and its neighbours. Moran's I index of spatial autocorrelation perfectly fits this purpose (Brown and Chung 2006). Moran's I estimates the correlation between the fraction Di of sect $D$ in building $i$ and the average fraction of sect $\mathrm{D}$ over the buildings within the neighbourhood $\mathrm{U}(\mathrm{i})$ of building $\mathrm{i}$ :

$$
\frac{N \sum_{i} \sum_{j \in U(i)} w_{i j}\left(D_{i}-\bar{D}\right)\left(D_{j}-\bar{D}\right)}{\left(\sum_{i} \sum_{j \in U(i)} w_{i j}\right) \sum_{i}\left(D_{i}-\bar{D}\right)^{2}}
$$

Where $\mathrm{N}$ is the number of buildings and $\bar{D}$ the average fraction of a sect $\mathrm{D}$ in Stamford-Hill. The influence wij of the neighbouring buildings $j \in U(i)$ on $i$ is calculated as wij $=1 / N U(i)$, where $N U(i)$ is the number of buildings in $U(\mathrm{i})$. The proximity of buildings is defined by a Voronoi partition constructed on the basis of the buildings' central points, as proposed by Benenson et al (2002).

According to the collected data, the Hassidic population in the research area of Stamford-Hill is growing (Figure 2). The area was initially populated by various Hassidic groups with North African, Persian and Adeni Jews steadily substituting for Chabad residents during the late 2000s. Close intra-group relations are responsible for the efficient information network that helps Haredi householders learn about vacancies from 
members of their own group. According to the data, $73 \%$ of Stamford-Hill's population either bought or rented their current apartment after receiving information through family and friends, whereas only $25 \%$ learned about it from agents and advertising (Table 2). Note that the distribution of information sources does not depend on affiliation to sects (chi-square test, $p \sim 0.4$ ).

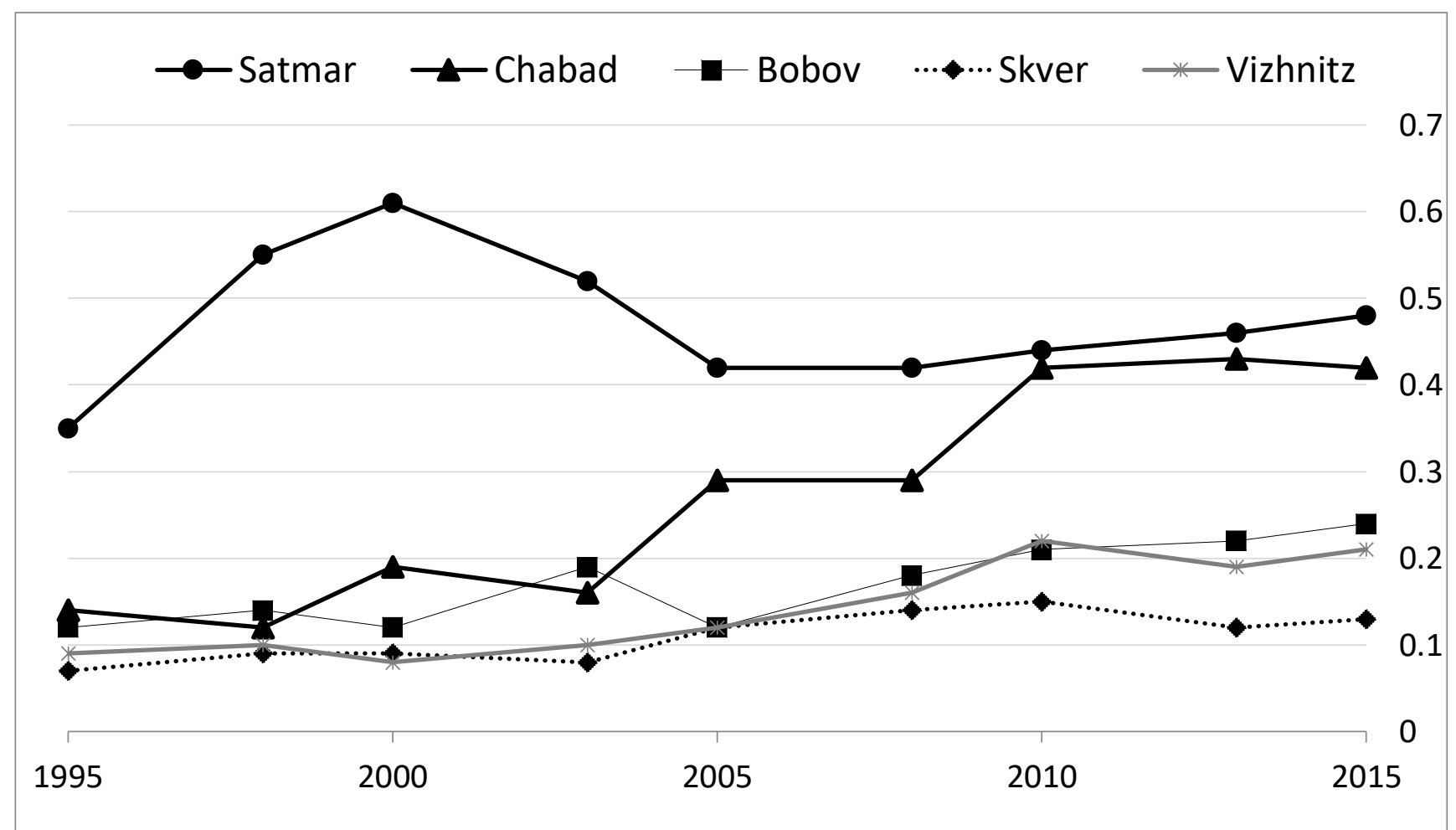

Figure 2: Population dynamics in the research area of Stamford-Hill: (percentages).

\begin{tabular}{lll}
\hline \hline Source of information & $\mathrm{N}$ & $\%$ \\
\hline Public advertisement & 36 & 3.1 \\
Real estate agents & 11 & 0.9 \\
Family & 704 & 60.4 \\
Friends & 307 & 26.4 \\
Other & 33 & 2.8 \\
Inheritance & 74 & 6.4 \\
\hline Total & 1165 &
\end{tabular}

Table 2: Sources of real estate information: How dwellers learned of vacant apartments prior to their purchase or rental 


\begin{tabular}{lllllllll}
\hline & & Bobov & Vizhnitz & Skver & Satmar & $\begin{array}{l}\text { Karlin- } \\
\text { Stolin }\end{array}$ & Adeni & Chabad \\
& $\mathrm{n}$ & & & & & & \\
\hline Neighbours & 927 & $89 \%$ & $91 \%$ & $79 \%$ & $61 \%$ & $86 \%$ & - & $56 \%$ \\
Institute & 167 & $10 \%$ & $6 \%$ & $16 \%$ & $19 \%$ & $14 \%$ & - & $26 \%$ \\
Price & 71 & $1 \%$ & $3 \%$ & $5 \%$ & $20 \%$ & $0 \%$ & - & $18 \%$ \\
\hline
\end{tabular}

Table 3: Importance of apartment cost, neighbours' identity and proximity to institutions in apartment choice by Haredi sect, Stamford-Hill (2015)

Table 3 shows that Haredi sects in Stamford-Hill share similar concerns (chi-square test, $p \sim 0.5$ ). Less than $26 \%$ of Stamford-Hill dwellers chose the location of Haredi institutions as their main concern. StamfordHill's location close to the city centre ensures the proximity of such institutions. Contrary to economic theory, only up to $18 \%$ of each group indicated that price was a critical issue for them. Most important rather is the fact that, despite the neighbourhood's reputation as a Haredi neighbourhood, more than $56 \%$ of Stamford-Hill dwellers from all sects reported that the identity of their immediate neighbours is their principal concern. As this stated preference appears to be shared by members of all sects, the research can assume that the Schellingtype mechanism of actively distinguishing between "friends" and "others" remains relevant within the Haredi haven of Stamford-Hill. Apparently, most of the neighbourhoods' dwellers feel the need for at least a few "friends" in order to feel at home in their apartment building. The study thus turned to investigate the impact of these declared preferences on the revealed preferences of Stamford-Hill's dwellers.

\section{Inter-building and intra-building segregation}

The survey data enabled reconstruction of Stamford-Hill's residential patterns for the entire period between 1995 and 2015 (Figure 3). Despite the stated preference for living in a "friendly" environment, those maps indicate a high level of spatial integration, with members of several sub-sects sharing apartment buildings and near neighbourhoods. 

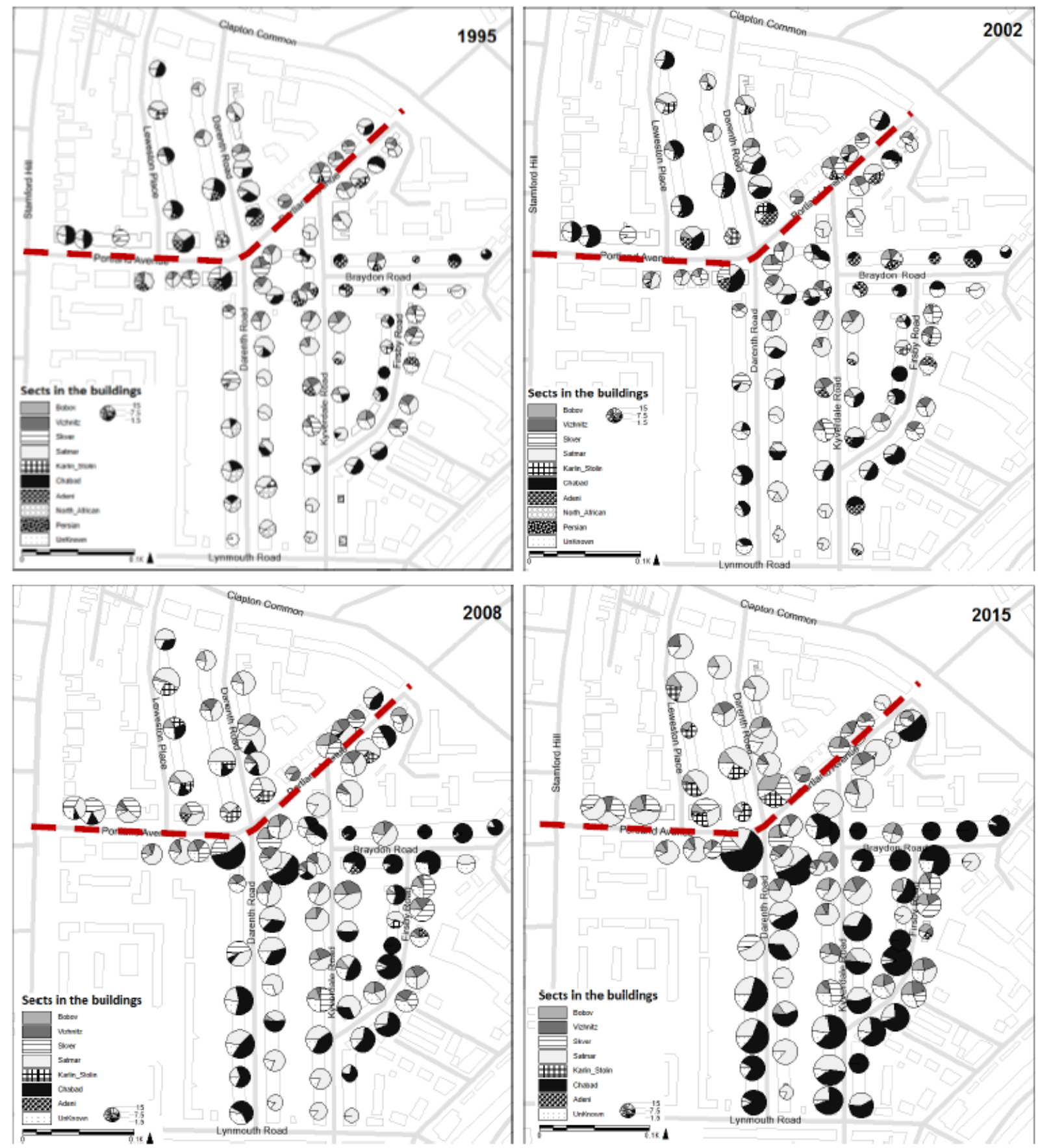

Figure 3: Spatial distribution of Bobov, Vizhnitz, Skver, Satmar, Karlin-Stolin, Chabad and non-Haredi Jewish sects in apartment buildings, Stamford-Hill 1995-2015.

Moran's I index appears relatively high for three sects (Figure 4). The dynamics of Moran's I index show that the Chabad and Satmar Hassidim are the most highly segregated sect in Stamford-Hill, although the residential segregation of the other sects has been steadily growing over the years. 


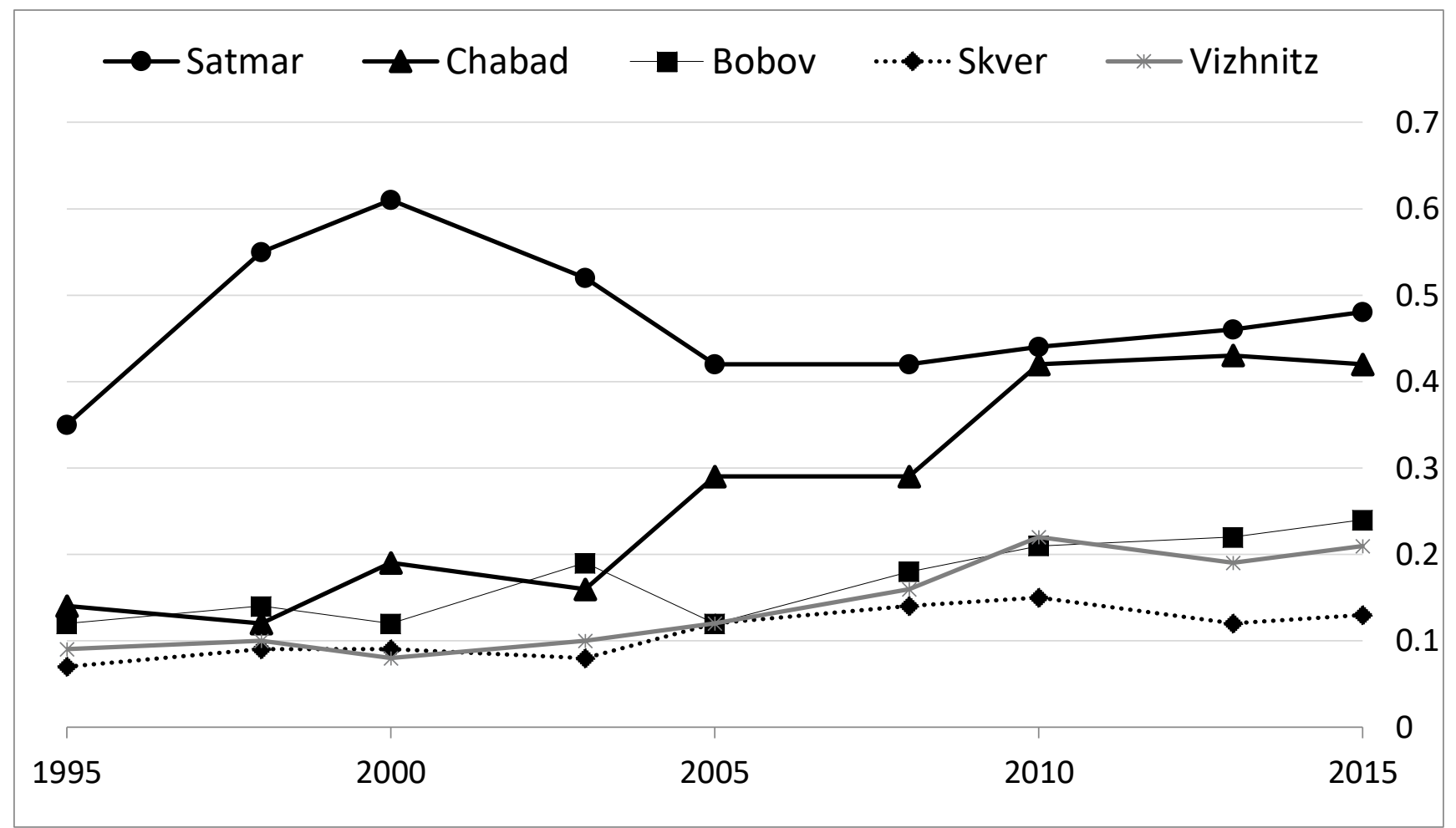

Figure 4: Segregation of Stamford-Hill sects as expressed by the Moran's I index of spatial autocorrelation, during the period of 1995 - 2015. To be significant at the $5 \%$ or $1 \%$ levels, the value of the Moran's I should be above 0.1 and 0.15 , respectively.

A high resolution look into the dynamics reveals the relation between the stated (Table 3 ) and the revealed residential preferences of the area's residents. To estimate the latter, for each sect $D$ the study calculated the fraction of D-families in each building that had a vacant apartment. Then, for each sect $D$, we now compared the average fraction of $D$-families in buildings the vacant apartment of which was chosen by new $D$-families, to the fraction of $D$-families in the rest of the buildings. For each sect $D$, the average fractions of friendly families in the buildings chosen and not chosen by D-families are presented in Table 4 . The buildings chosen by D-families show percentages of "friends" is up to two times higher than the buildings with vacant apartments ignored by D-families. This fundamental pattern of residential behaviour is consistent for all religious sects in Stamford-Hill, although weakening at the near neighbourhood level (Table 5). 


\begin{tabular}{|c|c|c|c|c|c|c|c|}
\hline \multirow[b]{3}{*}{ Sect D } & \multicolumn{6}{|c|}{ The apartment in the building was ... } & \multirow[b]{3}{*}{$\mathrm{P}$} \\
\hline & \multicolumn{3}{|c|}{ Chosen by members of $D$} & \multicolumn{3}{|c|}{ Not chosen by members of $D$} & \\
\hline & $\mathrm{N}$ & Mean & STD & $\mathrm{N}$ & Mean & STD & \\
\hline Bobov & 54 & 28.6 & 21.3 & 1128 & 18.4 & 19.7 & $<0.001$ \\
\hline Vizhnitz & 57 & 25.2 & 16.6 & 1125 & 17.6 & 16.2 & $<0.001$ \\
\hline Skver & 60 & 24.2 & 17.4 & 1122 & 17.7 & 16.1 & $<0.001$ \\
\hline Satmar & 663 & 35.8 & 32.6 & 519 & 13.2 & 17.8 & $<0.001$ \\
\hline Karlin-Stolin & 47 & 38.4 & 11.4 & 1135 & 15.6 & 12.4 & $<0.001$ \\
\hline Chabad & 207 & 27.9 & 17.2 & 975 & 16.8 & 15.8 & $<0.001$ \\
\hline
\end{tabular}

Table 4: Mean Percentage of "Friends" in Building "Chosen," and "Not Chosen" by Sect (1995 - 2015)

\begin{tabular}{|c|c|c|c|c|c|c|c|}
\hline \multirow[b]{3}{*}{ Sect $D$} & \multicolumn{6}{|c|}{ Apartment within the neighbourhood was ... } & \multirow[b]{3}{*}{$P$} \\
\hline & \multicolumn{3}{|c|}{ Chosen by members of $D$} & \multicolumn{3}{|c|}{ Not chosen by members of $D$} & \\
\hline & $\mathrm{N}$ & Mean & STD & $\mathrm{N}$ & Mean & STD & \\
\hline Bobov & 52 & 24.7 & 15.5 & 1018 & 9.8 & 10.2 & $<0.001$ \\
\hline Vizhnitz & 56 & 22.1 & 9.7 & 1014 & 7.6 & 9.1 & $<0.001$ \\
\hline Skver & 58 & 20.1 & 10.2 & 1012 & 8.2 & 10.4 & $<0.001$ \\
\hline Satmar & 659 & 37.1 & 22.1 & 411 & 14.7 & 12.3 & $<0.001$ \\
\hline Karlin-Stolin & 47 & 32.9 & 14.7 & 1023 & 21.2 & 25.4 & $<0.001$ \\
\hline Chabad & 198 & 24.6 & 13.5 & 872 & 15.2 & 11.8 & $<0.001$ \\
\hline
\end{tabular}

Table 5: Mean percentage of 'friends' in the near neighbourhood surrounding the buildings the apartment in which was 'chosen' and 'not chosen', by sect (1995 - 2015)

Note that although the relatively small number of Karlin-Stolin members is insufficient to express their segregation tendency by the Moran's I index (Figure 4), a comparison between the average fraction of families in buildings the vacant apartment of which was chosen by new families and the fraction of $D$-families in the rest of the buildings indicate that they effectively implement their stated preferences by residing in buildings occupied by "friends." As these preferences appear to weaken at the near neighbourhood level (Table 5), it is safe to conclude that they form a fundamental mechanism, providing people with a sufficiently strong sense of home and belonging.

The central role of the parochial realm (Hunter 1985; Lofland 2009) is now revealed: In addition to their efficient information network that helps Haredi householders learn about vacancies from members of their own group (Table 2), an individual-based mechanism is supporting the establishment of residential patterns. A high percentage of Haredi families reside in apartments vacated by householders of their own sect (Table 6). The high probability of an empty apartment being transferred to members of the same sect becomes 
a parallel, individual based mechanism supporting micro-congregation. Families can thus be assured that the level of "friendliness" in their building will not decrease.

\begin{tabular}{lrrrrr}
\hline \hline Sect & Bobov & Vizhnitz & Skver & Satmar & Chabad \\
\hline Fraction & 0.92 & 0.94 & 0.81 & 0.85 & 0.52 \\
$\mathrm{~N}$ & 101 & 110 & 71 & 265 & 279
\end{tabular}

Table 6: The fraction of members of a given sect who occupied an apartment vacated by a member of their own sect $(1983-2008)$

\section{Inter-sect relations}

The Schelling-type tendency to reside in buildings and neighbourhoods with a sufficiently high fraction of friends explains the evolution of residential patterns in populations consisting of two groups. This model, however, is insufficient to explain the case of Stamford-Hill, where householders from several groups compete for the same residential space. Moreover, in contradiction to Schelling's symmetric view of residential relationships, relations between Haredi sects are hierarchical. It is well-known, for instance, that Hassidim consider proximity to Chabad to be embarrassing (Friedman 1991), as Miriam (30's) explains:

"Two Chabad families moved to the building behind us last summer, so now we are considering to move out. We are renting, so we can do it. For other families it is also a nuisance. Their kids are talking to ours in the street, and they may be influenced by wrong ideas" (16 Sep. 2015).

One can assume that Hassidic householders would avoid residing in a building with one or more Chabad families, although Chabad householders may be tolerant toward Hassidic neighbours and even prefer them. It is also known that despite the differences between the Hassidic courts, there are there are marriage relations between other Hassidic groups. Which, if any, of the relationships between the sects are relevant for explaining residential patterns in Stamford-Hill?

To estimate the residential attitudes of members of sect $D$ toward members of other sects, the research compared the residential structure in buildings with vacancies that were/were not selected by householders belonging to $D$. If two buildings have the same fraction of families belonging to sect $D$ but different fractions of families of other sects, and D-newcomers prefer/avoid residence in one of those buildings, a comparison of the fractions of the other sects residing in these two buildings should reveal D's preferences in regards to the other sects in the building. This procedure was applied when the steady out-migration of non-Haredi householders from Stamford-Hill was almost completed (Figure 3). The analysis began with comparing "buildings of others" in which D-families did not reside at all at the moment of residential choice.

Satmar families are indifferent to the identity of others in the building, and can reside anywhere (Figure 3). This is not so for Bobov, Skver, Vizhniz and Karlin-Stolin householders. Satmar, if forced to choose apartments in "buildings of others," surprisingly choose houses with high fractions of Adeni and Chabad 
families. Here, for first time, the indirect impact of social status plays: As the Satmar presence spread in Stamford-Hill during this period, their social status provided them the power to select the most desirable locations. Satmars, appear to prefer buildings with less competition, although the non-Haredi residents in those buildings belong to sects "below them" in the neighbourhood social hierarchy. When "friends" reside in the building, all besides Bobov, Skver, and Vizhniz newcomers become indifferent to the proportions of others. They remain sensitive to the building's population structure and avoid/are deterred from buildings with more Chabad, but are attracted by more Satmars. Chabad families, however, avoid buildings with high fractions of Bobov, Skver, Vizhniz and Karlin-Stolin, and prefer or are steered to buildings with high fractions of Satmar and Adeni families.

This is another manifestation of the important role played by the social hierarchy in the formation of residential structure: Individuals belonging to higher status sects are in effect less concerned by the identity of others in the building, as long as there is at least one family of "friends." However, households with lower social status are much more limited in residential choices and end up with a greater presence of "friends" in an apartment house. In conclusion, individuals and households are sensitive to the identity of others in the buildings, and when they cannot find "friends" as close neighbours, they choose their residents according to the social hierarchy. Individuals from marginalized sects associate with households of other marginalized sects, whereas individuals located at the top of the social hierarchy are in effect free to choose their neighbours from all other sects. In the case of Satmars, they are also able to express their high social status by choosing cheaper apartments, located in buildings with non-Haredi households.

The last issue concerns the near neighbourhood (excluding the building itself). Comparing chosen and not-chosen buildings, the study compared sect percentages within the near neighbourhoods of buildings that had a vacant apartment. Only Chabad were found to be sensitive to the sect distribution of the near neighbourhood in addition to the building, and tend to avoid/are steered away from other Hassidim but the Satmars. Taken together, the need to live close to someone who shares the same faith, worldview, and lifestyle is shared by all the sects examined, the urge to avoid those who are "not friendly" is partial and weak.

Another interesting finding concerns the asymmetric nature of segregation attitudes. Chabad and the four Hasidic sects of Bobov, Skver, Karlin-Stolin and Vizhniz - relations, are one-way: Chabad avoid buildings where the percentage of those Hassidim is high, yet the Hassidim are less sensitive to the percentage of Chabad; Satmar are insensitive to the fraction of Chabad families in the building while Chabad prefer buildings with a higher percentage of Adeni. Resulting from the lack of symmetry, different sects face different limitations when choosing a new building. While individuals from higher in the social hierarchy focus on the building and tend to neglect the near neighbourhood, households of lower social status are more sensitive to the distribution of their sect in the near neighbourhood, as a compensation to the relative absence of a "friend" in the building, and are usually forced to choose apartments with a higher fraction of non-Haredi households.

The currents described above are coupled with other tendencies that have shaped the spatial configuration of Stamford-Hill throughout the years. For decades, Chabad families have concentrated around 
their institutions, on the northern area of Portland-Avenue and along Stamford-Hill Road, a major highway, considered less attractive than the neighbourhood's interior areas. Recently, Chabad have concentrated on the southern area of Portland Avenue (see Figure 5). All this leads to the assumption that the residential preferences of Chabad families manifest feelings of social exclusion rather than free choice between market alternatives.
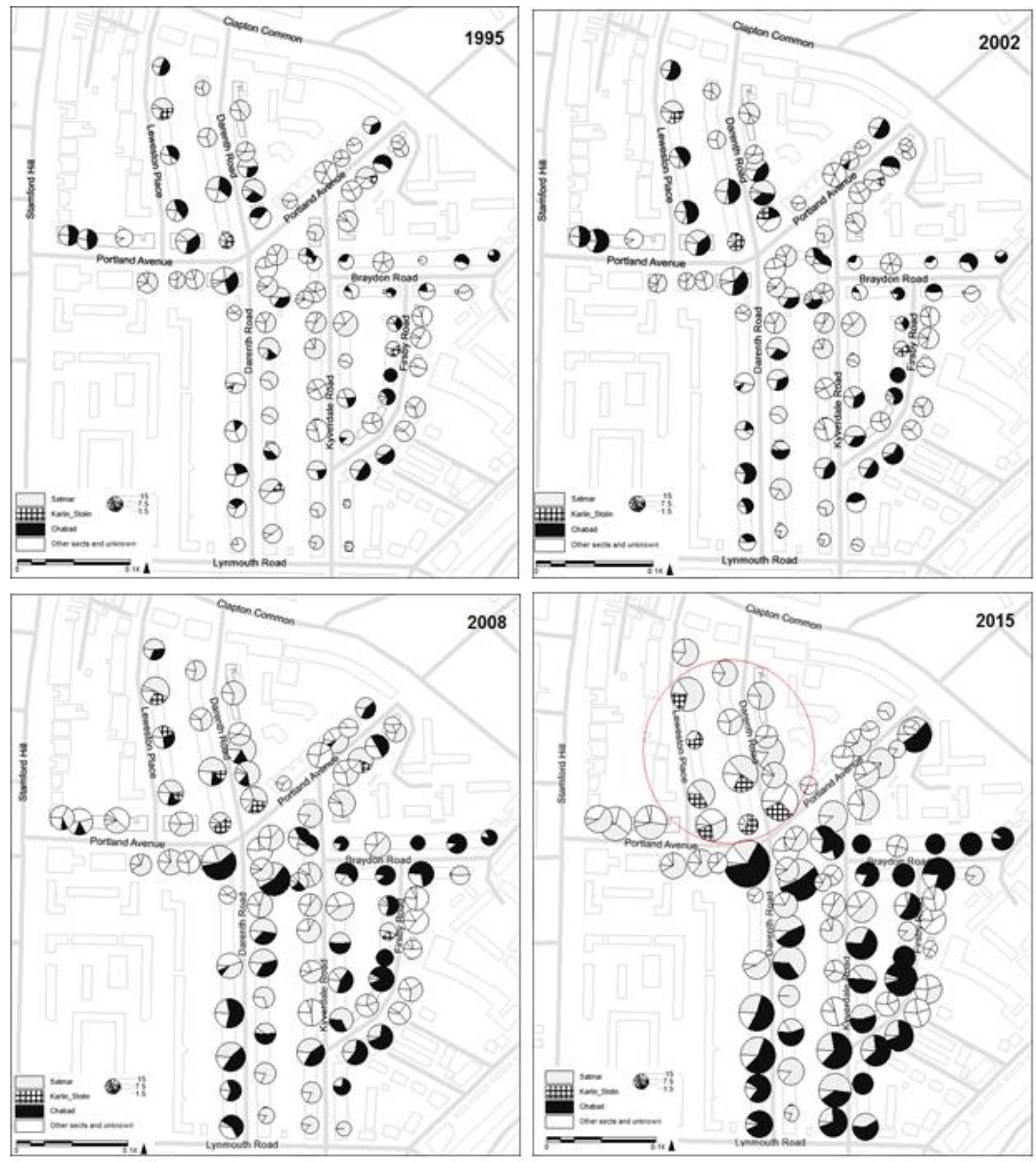

Figure 5: Dynamics of spatial distribution of the Satmar and Karlin-Stolin versus Chabad, the patterns for 1995, 2002, 2008 and 2015. 
Exclusion of Chabad from buildings is especially striking when compared with the segregated pattern of Karlin-Stolin. From the mid-1990s, Karlin-Stolins began to make themselves felt in the stronghold of the "Hasidic Hub". While they rarely managed to purchase apartments in the area, by $2015,73 \%$ of Karlin-Stolins continue to rent from Chabad (Figure 5, bottom row).

Regarding the apartments vacated by non-Haredi families, the Satmars' competitors are the Chabad. Chabad is taking advantage of their economic abilities, and are the first owners and renters of the apartments vacated by North African, Persian and Adeni families. The fraction of Non-Haredi families in the "buildings of others" chosen by both sects is essentially higher than the respective percentages in buildings not chosen. However, we assume that the occupation of these buildings by Satmar expresses their superior status and freedom of choice, whereas Chabad reside there as an expression of their social exclusion and lack of choice. In conclusion, our intra-sect and inter-sect analysis has revealed mechanisms of spatial differentiation through congregation with "friends" whilst selectively ignoring unwelcome "others." Since these mechanisms operate more strongly on the building than on the near neighbourhood level, it is appropriate to refer to the aggregate results under the heading "micro-segregation".

\section{Discussion and conclusions}

This study examines the impact of social relations and social identity on intra-urban segregation, focusing on the research area of Stamford-Hill. The literature assumes that non-economic forces, namely, communal relations and social considerations, are the main driving forces of internal neighbourhood segregation (Peach, 2006); while other economic factors have less influence on the residential decision-making of traditional communities. This is especially true for Stamford-Hill's Haredi population. Generally, relatively intense devotion to lifestyle lead the Haredi population to focus on sect affiliation and enforce residential homogeneity despite turnover in the buildings and neighbourhoods. Once economic considerations are set aside, Stamford-Hill householders are free to direct their attention to inter- and intra-sect relations and emerging social patterns when choosing a residence.

The study reveals micro-segregation dynamics operate at the level of the household as well as at the neighbourhood level. The research is pioneering in three respects: (1) using the combination of mixed methods in order to provide a useful technique for studying micro dynamics within a community; (2) study of a relevant example of spatial interactions between population groups that are similar in many respects, while each is interested in preserving its unique cultural identity; and (3) the research findings extend Schelling's theory regarding the symmetric relations between two groups by adding two essential points. The unique information collected via in-depth door-to-door survey made it possible to compare stated and revealed preferences at the household level and to reveals powerful migration mechanisms that govern this segregation over two decades. The religious affiliation of the building's inhabitants proves to be the motivating force for dwellers from all sects. Non-Orthodox people living in Stamford-Hill are leaving because Haredim from the two poles of the local social spectrum - the high-ranked Satmar and low-ranked Chabad-quickly occupy their vacated apartments. The 
Hassidic group of Karlin-Stolins plays the role of the most highly segregated sect, most anxious to congregate with one another. Other Hassidic sects of Bobov, Skver and Vizhniz avoid specific others in the building level, such as the Chabad. Chabad is the only group paying almost the same amount of attention to the number of "friends" in a nearby building as in their own. Chabad are socially excluded from other Hassidic-dominated areas. Whether Chabad tend to avoid other Hassidim or feel unwelcome by them, they are nevertheless more likely to move in with the marginal non-Haredi and Satmar.

The study shows that micro-segregation is not only inevitable but also desirable for maintaining the diversity. The case study of Stamford-Hill is a laboratory for studying micro-segregation, offers lessons to the broad field of inner-city dynamic processes. First, instead of Schelling's "white" and "black" dualism, the study examined several groups residing in the same urban neighbourhood. Although Schelling's research was not based on such a highly specific group of the population, it still shows that beside the basic urge to live among "friends," individuals' decisions are affected by the relations to each of the other groups. Thus, individuals belonging to high-status groups are mainly sensitive to the fraction of people of their own sect. As assumed by Schelling (1978), those individuals are satisfied with a sufficient number of "friends" in a building and remain insensitive to the proximity of specific "others." Conversely, individuals belonging to marginal and low-status groups are selectively sensitive to the presence of others: in addition to preferring buildings hosting a sufficient number of "friends," they acquire micro-environments with low fractions of individuals belonging to inhospitable and high status groups. A second contrast with Schelling's model moves closer to the real world. Despite the need to study multi-family buildings, researchers tend to avoid studying multi-parametric situations of this kind because of the multiplicity of "clues" demanded by the research. This study supplies these clues and managed to explore how the revealed behaviour of individuals maintains the diversity.

The micro-segregation pattern could be relevant to many other inner-city situations, where various population groups live together in dense urban areas. This mixed methods research framework of cultureoriented micro-residential analysis, offers reasoned answers to defined situations in Stamford-Hill. However, this intensive, multi-method study of a very specific religious and residential context is also general enough to be applied to other multi-parametric situations occurring in dense inner-city neighbourhoods inhabited by different groups and religious communities, like New-York, Montreal, Manchester and Jerusalem. From the perspective of urban dynamics, the Haredi population's behaviour exemplifies the influence of social relations within a microcosm of small communities with bold leadership in the spatial organization of a densely populated urban area. A specific type of relationship between individuals and the community is needed for constructing as well as maintaining such a spatial order. Analysing how ultra-religious identities shape segregation dynamics, raises questions regarding the social mechanisms that created and continue to maintain this segregation. However, the research has several limitations. Firstly, the interviewees cooperated with the researchers, but this may not be the case in other scenarios. Secondly, this type of research may only be suitable for inner-cities areas, and not applicable elsewhere. Thirdly, the proposed approach is costly and requires a substantial investment of professional time for gathering detailed information. Further research may reveal the 
degree to which micro-segregation is a more general mechanism applicable for seemingly heterogeneous urban spaces.

\section{REFERENCES}

Abrams D, Hogg M (1990). Social Identification, Self-Categorization and Social Influence, in W. Stroebe and M. Hewstone (eds.), European Review of Social Psychology, 1(1):195-228. Chichester: Wiley.

Arbaci, S. (2007). Ethnic segregation, housing systems and welfare regimes in Europe. International Journal of Housing Policy, 7(4), 401-433.

Atkinson R and Flint J (2004) Fortress UK?Gated communities, the spatial revolt of the elites and time-space trajectories of segregation. Housing Studies 19(6): 875-892.

Andersen, H.S., Andersson, R., Wessel, T and Vilkama, K. (2016). The impact of housing policies and housing markets on ethnic spatial segregation: comparing the capital cities of four Nordic welfare states, International Journal of Housing Policy, 16(1): 1-30

Benenson I Omer I Hatna E, (2002), Entity-based modeling of urban residential dynamics - the case of Yaffo, Tel-Aviv. Environment and Planning B. 29, 491-512.

Berg, M. L., \& Sigona, N. (2013). Ethnography, diversity and urban space. Identities, 20(4), 347-360.

Berman E. (2009) Voices of Outreach: The Construction of Identity and Maintenance of Social Ties among Chabad-Lubavitch Emissaries, Journal for the Scientific Study of Religion, 48(1):69-85,

Bisin, A., Patacchini, E., Verdier, T., \& Zenou, Y. (2016). Bend it like Beckham: Ethnic identity and integration. European Economic Review, 90, 146-164.

Blumenstock, J., Toomet. O., Ahas, R., and Saluveer, E. (2015) Neighborhood and Network Segregation: Ethnic Homophily in a Silently Separate Society, Proc. NetMob, Cambridge, MA, USA,

Boal FW. (2010). From Undivided Cities to Undivided Cities: Assimilation to Ethnic Cleansing. Journal Housing Studies 14(5): 585-600

de Souza, Briggs. (2005). The Geography of Opportunity, Washington, DC: Brookings Institution Press.

Brown LA., Su-Yeul Chung. (2006). Spatial Segregation, Segregation Indices and the Geographical Perspective. Population, Space and Place 12(2):125-143.

Butler, T., Hamnett, C., Ramsden, M. and Webber, R. 2007: The best, the worst and the average: secondary school choice and education performance in East London. Journal of Education Policy 22, 7-29.

Catney, G., and Simpson, L. (2010). Settlement area migration in England and Wales: Assessing evidence for a social gradient. Transactions of the Institute of British Geographers, 35(4), 571-584.

Clark, W.A.V. and Dieleman, F.M. (1996), Households and Housing: Choice and Outcomes in the Housing Market, Rutgers: Center for Urban Policy Research, New Brunswick, NJ. 
Clark WAV and Coulter R. (2015). Who wants to move? The role of neighbourhood change. Environment and Planning A 47 (12), 2683-2709.

Colomb, C. (2017). Participation and conflict in the formation of neighbourhood areas and forums in 'superdiverse' cities. Localism and Neighbourhood Planning: Power to the People?, 127.

Crowder, Kyle D., Jeremy Pais, and Scott J. South. (2012). Neighborhood Diversity, Metropolitan Constraints, and Household Migration. American Sociological Review 77:325-53.

DESTINATION Hackney, 2015 (http://home.destinationhackney.co.uk/)

Fielding, T. (2012) Migration in Britain: Paradoxes of the Present, Prospects for the Future, Cheltenham: Edward Elgar.

Finke R. (1997). The Consequences of Religious Competition: Supply-Side Explanations for Religious Change. In L. A. Young (ed.), Rational Choice Theory and Religion: Summary and Assessment, 45-65. New-York: Routledge Finney, N. and Jivraj, S. (2013) Ethnic group population change and neighbourhood belonging in Britain.

Urban Studies

Friedman M. (1991). The Haredi Ultra-Orthodox Society: Sources Trends and Processes. Jerusalem: The Jerusalem Institute for Israel Studies (Hebrew).

Giddens A. (1984). The Constitution of Society: Outline of the Theory of Structuration. Berkeley and Los Angeles: University of California Press.

Gonen A. (2006). Between Torah Learning and Wage Earning The London Experience and Lessons for Israel. Jerusalem: The Floersheimer Institute for Policy Studies (Hebrew).

Green A. (2001). Typologies of Leadership and the Hasidic Zaddiq. In D. Assaf (ed.), Zaddik and Devotees: Historical and Social Aspects of Hasidism, 422-44. Jerusalem: Zalman Shazar (Hebrew).

Guest, M. A, K. J Cover, L. R Matsueda, and E. C Kubrin. (2006). Neighborhood Context and Neighboring Ties. City \& Community, 5(4):363-385.

Hunter A. (1985). Private, Parochial and Public Social Orders: The Problem of Crime and Inactivity in Urban Communities. In P. Kasinitz (ed.), Metropolis: Center and Symbol of our Times, 204-225. NY: NY University Press.

Ibraimovic, T. and Masiero, L (2014). Do Birds of a Feather Flock Together? The Impact of Ethnic Segregation Preferences on the Neighbourhood Choice. Urban Studies, 51(4), 693-711.

Interlink, The spatial needs of the Charedi community in Stamford-Hill, 2010

Johnston, J. Ron, Michael Poulsen, and James Forrest. (2007). The Geography of Ethnic Residential Segregation: A Comparative Study of Five Countries. Annals of the Association of American Geographers 97(4), 713-738.

Karsten, L. (2007). Housing as a way of life: Towards an understanding of middle-class families' preference for an urban residential location. Housing Studies, 22(1), 83-98.

Kasarda DJ. (1978). Urbanization, Community, and the Metropolitan Problem. In D Street (ed.), Handbook of Contemporary Urban Life, 27-57. San Francisco: Jossey-Bass. 
Kalmijn, M. (1998). Intermarriage and Homogamy: Causes, Patterns, Trends. Annual Review of Sociology. 24(1), $395-421$

Krivo, L. J., Peterson, R. D., Rizzo, H., \& Reynolds, J. R. (1998). Race, segregation, and the concentration of disadvantage: 1980-1990. Social Problems, 45(1), 61-80.

Kusenbach, M. (2008). A Hierarchy of Urban Communities: Observations on the Nested Character of Place. City \& Community 7(3):225-249.

Levy, D., and Lee, C.K.C. (2011) Neighbourhood identities and household location choice: estate agents' perspectives. Journal of Place Management and Development 4(3), 243-263.

Lloyd, C. D., Shuttleworth, I. G., \& Wong, D. W. (Eds.). (2015). Social-spatial segregation: Concepts, processes and outcomes. Policy Press.

Lofland, HL. (2009). The Public Realm: Exploring the City's Quintessential Social Territory. New Brunswick, NJ: Aldine Transaction Publications.

Massey, D. S. and Denton, N. (1993). American apartheid: segregation and the making of the underclass Harvard University Press, Cambridge MA

McGarrigle, J. and Kearns, A. (2009), Living apart? Place, identity and South Asian residential choice, Housing Studies, Vol. 24 No. 4, pp. 451-75.

McPherson, M., Smith-Lovin, L., and Cook. MJ (2001) Birds of a Feather: Homophily in Social Networks Annu. Rev. Sociol. 27:415-444

Musterd, s., Gent, WPC., Das, M. and J. Latten (2016). Adaptive behaviour in urban space:

Residential mobility in response to social distance. Urban Studies 53(2) 227-246

Office for National Statistics,(2015)

https://www.ons.gov.uk/economy/inflationandpriceindices/bulletins/housepriceindex/jan2017\#uk-alldwellings

Peach, C. (2006). Islam, ethnicity and South Asian religions in London 2001 census, Trans Institute of British Geographers, 31, 3, 353-370.

Phillips D (2009) Minority ethnic segregation, integration and citizenship: A European perspective. Journal of Ethnic and Migration Studies 36(2): 209-225.

Ratcliffe, P. (2009) Re-evaluating the links between 'race' and residence. Housing Studies,24 (4): 433-450. ISSN 0267-3037

Rosenbaum, J. E. (1995). Changing the geography of opportunity by expanding residential choice: Lessons from the Gautreaux program. Housing Policy Debate, 6(1), 231-269.

Sakoda MJ. (1971). The Checkerboard Model of Social Interaction. Journal of Mathematical Sociology 1(1):119132.

Schelling CT. (1978). Micromotives and Macrobehavior. New-York: WW Norton.

Sennett, R. (2012). Together: The Rituals, Pleasures, and Politics of Cooperation, Yale 
Sharma M. (2012). A Geographic Perspective on Intra-Urban Racial/Ethnic Diversity, Segregation, and Clustering in Knoxville, Tennessee: 1990-2000. Applied Geography, 32(2):310-323.

Shilhav Y, Friedman M. (1985). Growth and Segregation: The Haredi Community of Jerusalem. Jerusalem: The Jerusalem Institute for Israel Studies (Hebrew).

Shuttleworth, I, Barr, P.J and Gould, M (2012) Does Internal Migration in Northern Ireland Increase Religious and Social Segregation? Perspectives from the Northern Ireland Longitudinal Study (NILS) 2001-2007, Population, Space and Place, 19, 72-86.

Smith, DP and Jons, H (2015) Education and internal migration. In Smith, DP, Finney, N, Halfacree, K, Walford, N (eds) Internal Migration: Geographical Perspectives and Processes. Farnham: Ashgate, pp.47-63.

South, S. J., Crowder, K., \& Pais, J. (2011). Metropolitan Structure and Neighborhood Attainment: Exploring Intermetropolitan Variation in Racial Residential Segregation. Demography, 48(4), 1263-1292.

Speare, A, Goldstein S, Frey H. (1975). Residential Mobility, Migration, and Metropolitan Change. Cambridge, MA: Ballinger Pub.

Tajfel H. (1972). Social Categorization. In S.Moscovici (ed.), Introduction a La Psychologie Sociale, 1, 272-302. Paris: Larousse.

Tausch N, Hewstone M, Schmid K, Hughes J, Ed Cairns. (2011). Extended Contact Effects as a Function of Closeness of Relationship with Ingroup Contacts. Group Processes \& Intergroup Relations 14(2):239-254.

Twigger-Ross, C. and Uzzell, D. (1996), Place and identity processes, Journal of Environmental Psychology, Vol. 16 No. 3, pp. 205-20.

Valins, O. (2003). Stubborn Identities and the Construction of Socio-Spatial Boundaries: Ultra-Orthodox Jews Living in Contemporary Britain. Transactions of the Institute of British Geographers 28(2):158-175.

Waterman S and Kosmin B A 1988 Residential patterns and processes: a study of Jews in three London boroughs. Transactions of the Institute of British Geographers 13 75-91

Wirth L. (1928/1998). The Ghetto Chicago: University of Chicago Press (Republished 1998, Transaction Pub). 